\title{
AKTUÁLNÍ VÝVOJ EVROPSKÉ PRÁVNÍ ÚPRAVY V OBLASTI EKODESIGNU VÝROBKÜ*
}

\author{
TEREZA FABŠÍKOVÁ
}

\begin{abstract}
Current Developments of European Legislation in Product Ecodesign
Ecodesign as a complex approach to product design, considering all impacts on the environment during the whole life cycle of a product, is an important factor in the concept of circular economy. The presented paper focuses on the issue of current development in the field of the European ecodesign regulation, emphasizing mainly the topic of the shift from energy efficiency to resource and material efficiency. Future requirements on ecodesigned products and possible changes in the Ecodesign Directive are presented and discussed.
\end{abstract}

Keywords: ecodesign; circular economy; Ecodesign Directive; material efficiency; resource efficiency

Klíčová slova: ekodesign; oběhové hospodářství; směrnice o ekodesignu; efektivnost zdrojů a materiálů

DOI: $10.14712 / 23366478.2019 .29$

\section{ÚVOD}

Evropská právní úprava ekodesignu výrobků, tedy př́stupu k designu, který již v návrhové fázi výrobku řeší jeho budoucí ekologické dopady, je v evropském právu zastřešována tzv. směrnicí o ekodesignu. ${ }^{1}$ Tato směrnice se dosud zaměřuje především na energetickou účinnost produktů, ${ }^{2}$ a představuje tak poměrně úzké pojetí pojmu ekodesign, limitované pouze na tento aspekt. V souvislosti se stále více se prosazující koncepcí oběhového hospodářství v rámci $\mathrm{EU}^{3}$ se však do popředí dostává otázka změny tohoto př́stupu v evropské legislativě a s tím související revize rámcové směrnice. ${ }^{4}$ Akční plán EU pro oběhové hospodářství ${ }^{5}$ v souvislosti s tím výslovně uvádí,

* Tento př́spěvek vznikl v rámci programu podpory vědních oborů Univerzity Karlovy PROGRES Q 16 Environmentální výzkum.

1 Směrnice Evropského parlamentu a Rady 2009/125/ES ze dne 21. ř́inna 2009 o stanovení rámce pro určení požadavků na ekodesign výrobků spojených se spotřebou energie. Dále jen „směrnice o ekodesignu“.

2 Srov. napřs. směrnice o ekodesignu, bod 14 odůvodnění.

3 Srov. např. dokumenty Evropské komise v rámci „Circular Economy Package“, http://ec.europa.eu /environment/circular-economy/index_en.htm [24. 5. 2019].

4 Srov. DALHAMMAR, C. Promoting Energy and Resource Efficiency through the Ecodesign Directive. Scandinavian Studies in Law, 2014, sv. 59, s. 158.

5 Akční plán EU pro oběhové hospodářství, s. 3. Dostupný na: https://eur-lex.europa.eu/resource.html ?uri=cellar:8a8ef5e8-99a0-11e5-b3b7-01aa75ed71a1.0005.02/DOC_1\&format=PDF [24. 5. 2019]. Srov. též Zpráva o provádění směrnice o ekodesignu (2017/2087(INI)), s. 3. Dostupná na: http://www.europarl .europa.eu/doceo/document/A-8-2018-0165_CS.pdf [25. 5. 2019]. 
že oběhové hospodářství začíná na samém počátku životního cyklu výrobků, tedy již ve fázi navrhování. Sedmý akční plán pro životní prostředí v této souvislosti upozorňuje, že $80 \%$ dopadů na životní prostředí má původ již v návrhové fázi. ${ }^{6}$ Právě ekodesign v širším pojetí je tedy současnými dokumenty vznikajícími na poli Evropské unie považován za zásadní faktor v oběhovém hospodářství. ${ }^{7}$

\section{POJEM EKODESIGN A PŮSOBNOST SMĚRNICE}

Ekodesign je možné charakterizovat jako př́stup k navrhování, jehož cílem je snížit dopady produktu na životní prostředí v průběhu jeho celého životního cyklu. Směrnice o ekodesignu popisuje ekodesign jako preventivní př́stup, který má optimalizovat vliv výrobků na životní prostředí při současném zachování jejich funkčních vlastností. ${ }^{8}$ Ačkoli směrnice ve svém odůvodnění uvádí definici pojmu, který jazykově odpovídá širšímu pojetí ekodesignu, samotný text směrnice se věnuje spíše energetické účinnosti. Tomuto př́stupu pak zcela odpovídají četná nařízení, ${ }^{9}$ která na směrnici navazují a jiné aspekty než spotřebu energie řeší zcela výjimečně. ${ }^{10}$ Dikce odůvodnění směrnice však představuje vhodný základ pro současnou a budoucí změnu ve vnímání ekodesignu na evropské normotvorné úrovni.

Akcentování energetické účinnosti odpovídá taktéž okruh výrobků, na něž se směrnice vztahuje. Po príijetí původní verze ${ }^{11}$ se jednalo pouze o produkty energii přímo spotřebovávající, $v$ současnosti (od r. 2009) směrnice může zahrnovat i produkty spojené se spotřebou energie, tedy takové, které určitým způsobem ovlivňují hospodaření s energií (izolační materiály, vodovodní kohoutky, apod.). V souvislosti s novými ekologickými požadavky na výrobky však nelze do budoucna vyloučit další změny ve věcné působnosti směrnice a její rozšíření i na výrobky, ${ }^{12}$ které př́ímo neovlivňují spotřebovávání energie (ve smyslu plýtvání). Tyto výrobky je sice pravděpodobně možné začlenit do kategorie výrobků spojených se spotřebou energie v širším smyslu (např. i výroba skleněné láhve je spojená se spotřebou energie), avšak lze očekávat, že pokud by k rozšíření výčtu produktů, na které směrnice dopadá, $\mathrm{v}$ budoucnu došlo, byl by i v jejím názvu nově akcentován přechod od energetické účinnosti k efektivnosti zdrojů a materiálů. Pravděpodobně by taková změna byla správnějšś i z hlediska koncepce směrnice jako rámcové, nebot' by bylo zřetelnější, jaké oblasti věcná působnost směrnice zahrnuje.

${ }^{6}$ Sedmý akční program pro životní prostředí, s. 183, bod 36. Dostupný na: https://eur-lex.europa.eu /legal-content/CS/TXT/PDF/?uri=CELEX:32013D1386\&from=EN [25. 5. 2019].

7 Tamtéž.

8 Směrnice o ekodesignu, bod 5 odůvodnění.

9 V současnosti se jedná o nařízení upravující 28 skupin výrobků.

10 Výjimkou je např. problematika nebezpečných látek používaných při výrobě televizorů a odpadů vznikajících po skončení životního cyklu těchto přístrojů (odst. 7 nařízení komise ES č. 642/2009), požadavky na obsah a emise rtuti (odst. 7 nařízení č. 244/2009 o nesměrových světelných zdrojích), či otázka akustické hladiny v př́ípadě ohř́ívačủ teplé vody.

11 Směrnice Evropského parlamentu a Rady 2005/32/ES ze dne 6. července 2005 o stanovení rámce pro určení požadavků na ekodesign energetických spotřebičů.

12 Zpráva o provádění akčního plánu pro oběhové hospodářství ze dne 4. 3. 2019 COM (2019) 190 final, s. 3. Dostupná na: https://eur-lex.europa.eu/legal-content/CS/TXT/PDF/?uri=CELEX:52019DC0190\&from $=\mathrm{EN}[30.5 .2019]$. 


\section{ZMĚNA V PŘÍSTUPU K EKODESIGNU}

Řada dokumentů přijímaných $\mathrm{v}$ rámci EU v posledních letech zmiňuje v souvislosti s oběhovým hospodářstvím nutnost rozšíření pojetí ekodesignu směrem ke komplexnějšímu př́stupu hodnocení ekologických aspektı̊ výrobků a minimalizaci jejich ekologických dopadů v průběhu celého životního cyklu. ${ }^{13}$ Akční plán EU pro oběhové hospodářství $\mathrm{v}$ této souvislosti výslovně uvádí, že Komise má $\mathrm{v}$ rámci směrnice o ekodesignu klást důraz na požadavky oběhového hospodářství. ${ }^{14}$ Jedním z nejvýznamnějších dokumentů je v této oblasti Pracovní program „Ekodesign“ pro roky 2016-2019, který výslovně uvádí posun od úzkého pojetí ekodesignu, ${ }^{15}$ ryze limitovaného na oblast energetické účinnosti, $\mathrm{k}$ tzv. účinnosti využívání materiálů a zdrojů. Ekodesign se zde výslovně propojuje s oběhovým hospodářstvím a akcentuje se posuzování celého životního cyklu výrobků. ${ }^{16}$

V této souvislosti jsou stanoveny hlavní oblasti týkající se výrobků, na které by se do budoucna měla normotvorba vztahovat. Po analýze relevantních dokumentů lze shrnout, že budoucí regulace by se měla zabývat především životností produktů, ${ }^{17}$ jejich opravitelností, možnostmi jejich složení a rozložení a dostupností náhradních dílů, možnostmi jejich zdokonalení a modernizace, možnostmi jejich znovupoužití nebo znovupoužití jejich součástí a recyklací. ${ }^{18} \mathrm{~V}$ prŕpadě výrobků, které jsou závislé na fungování softwaru, je pak v souvislosti s životností zásadní možnost aktualizace softwaru. ${ }^{19}$

\section{DƯVODY PRO DALŠÍ REGULACI EKODESIGNU}

Při př́ípravě nových požadavků na design výrobků vyvstává otázka, zda je právní regulace navrhování produktů účelná a vhodná. Na jedné straně lze argumentovat tím, že design je disciplína spíše umělecká, a jako takový by neměl být př́íliš regulován. Na druhé straně ale stojí fakt, že cílem produktového designu je návrh produktu a toto zřejmě nelze oddělit od jeho budoucího fungování a uvědomování si ekologických dopadů. $\mathrm{O}$ tom nakonec svědčí i současný důraz celé řady návrhářů na uvědomělost $\mathrm{v}$ oblasti ekologie. ${ }^{20} \mathrm{~V}$ současné době můžeme zaznamenat určitý dobro-

13 Např. Akční plán EU pro oběhové hospodářství, Sedmý akční program pro životní prostř̌edí, Pracovní program „Ekodesign“ 2016-2019.

14 Akční plán EU pro oběhové hospodářství, op. cit., s. 4.

15 Srov. BUNDGAARD, A. et al. From energy efficiency towards resource efficiency within the Ecodesign Directive. Journal of Cleaner Production, 2017, vol. 144, s. 359-360.

16 Pracovní program „Ekodesign“ 2016-2019. COM (2016) 773, s. 2-3. Dostupný na: http://ec.europa.eu /DocsRoom/documents/20375 [30. 5. 2019].

17 Srov. zejména Zpráva o delší životnosti výrobků: př́nosy pro spotřebitele a společnost (2016/2272 (INI)). Dostupné na: http://www.europarl.europa.eu/doceo/document/A-8-2017-0214_CS.pdf [30. 5. 2019].

18 Sdělení Komise Směrem k oběhovému hospodářství: program nulového odpadu pro Evropu ze dne 25. 9. 2014 COM (2014) 398 final/2. Dostupné na: https://eur-lex.europa.eu/legal-content/CS/TXT/PDF /?uri=CELEX:52014DC0398R(01)\&from=EN [31. 5. 2019].

19 Zpráva o delší životnosti výrobků, op. cit., s. 13

20 Jedná se především o volbu materiálů, tedy např́iklad využívání recyklovaných plastů a textilu, nahrazování plastů jinými materiály, recyklace plastů či rybářských sítí nalezených v mořích, využívání přírodních, 
volný př́iklon $\mathrm{k}$ návrhům zohledňujícím ochranu životního prostředí, je tedy vhodné přejít $\mathrm{k}$ určitému typu právní regulace?

V této souvislosti je nutné si uvědomit, že design je velmi úzce spjat s fungováním komerčních subjektů různé velikosti, a proto, za účelem dosažení pozitivních výsledků v oblasti vlivu výrobků na životní prostředí, je nutné sledovat a ovlivňovat chování právě těchto subjekti̊. Samotné rozhodnutí návrhářu totiž v praxi nemusí být dostatečné. Komerční subjekty se snaží maximalizovat své zisky a v zásadě jsou tak ovlivňovány pouze stimulací ekonomickou nebo právní. V teorii tak lze zaznamenat názory, že jestliže chceme začlenit postupy ekodesignu do fungování komerčních subjektů, je nutné tak učinit jednou $\mathrm{z}$ těchto cest. ${ }^{21} \mathrm{~V}$ právu životního prostředí jsou běžně využívané ekonomické nástroje, založené na pozitivní či negativní ekonomické stimulaci subjektů, ${ }^{22}$ a nástroje dobrovolné, které velmi často stojí na principu ekonomické stimulace také. ${ }^{23}$ Směrnice o ekodesignu v bodě 5 odůvodnění představuje ekodesign jako tzv. strategii dvojího zisku, tedy postup, který je výhodný ekologicky i ekonomicky. Využití právních nástrojů, at' již př́mého, či nepř́mého působení se tak i v této oblasti jeví jako vhodné.

\section{PROBLÉMY SPOJENÉ S REGULACÍ EKODESIGNU}

Dalš́i otázkou je, které oblasti produktových návrhů regulovat a jakým způsobem. Již současný vývoj nasvědčuje tomu, že zvolit vhodnou formu regulace jednotlivých aspektů životního cyklu výrobků nebude snadné a v souvislosti s každou jednotlivou oblastí je třeba vyřešit řadu souvisejících otázek. Aby bylo možné upravit ekodesign účinně a správně, je především nutné nashromáždit velké množství informací o konstrukci a fungování jednotlivých skupin výrobkủ. Již prvotní studie ukazují, že toto může být velmi komplikované. ${ }^{24}$ Př́kladem složitého stanovování produktových kritérií může být i nedávný spor společnosti Dyson a Evropské komise. ${ }^{25}$

Některé dílčí problémy je př́ikladem možné ukázat na oblasti životnosti výrobků. Zde je problematické určit, jak dlouhou životnost vlastně bude možné na výrobcích požadovat vzhledem k současným technologickým možnostem a vynaložení jakých finančních nákladů na prodloužení životnosti je možné na výrobcích požadovat. S tím se pojí i problematika inovačních cyklů a stupně inovace, tedy otázka, jakým způsobem

rychle se obnovujících materiálů (např. bambus), vývoj nových materiálů (zejména biologicky odbouratelných plastů či naturálních kompozitů). Dále se jedná o ekologicky uvědomělý př́stup $\mathrm{k}$ výrobě, tedy zejména o omezování použití škodlivých látek či technologií výrazně zatěžujících životní prostředí.

21 BORCHARD, M. et al. Redesign of a component based on ecodesign practices: environmental impact and cost reduction achievements. Journal of Cleaner Production, 2010, s. 55.

22 DAMOHORSKÝ, M. et al. Právo životního prostředí. 3. vyd. Praha: C. H. Beck, 2010, s. 36-46.

23 Samotný ekodesign je někdy mezi dobrovolné nástroje ochrany životního prostředí také řazen, zejména pokud je postupováno podle normy ISO.

24 The Durability of Products - Final Report, srpen 2015, s. 164. Dostupná na: http://publications.europa.eu /resource/cellar/6c325b55-7352-11e5-86db-01aa75ed71a1.0001.01/DOC_1 [2. 6. 2019].

25 Rozsudek ze dne 8. listopadu 2018, Dyson v. Komise, T-544/13 RENV, ECLI:EU:T:2018:761. Jednalo se o kritéria určování energetické účinnosti vysavačů, kdy společnost Dyson žalovala Evropskou komisi z důvodu nesprávného určení metodologie. Výsledkem řízení bylo zrušení nařízení č. 665/2013 ze dne 3. května 2013, kterým se doplňuje směrnice Evropského parlamentu a Rady 2010/30/EU, pokud jde o uvádění spotřeby energie na energetických štítcích. 
prodlužovat životnost u výrobků, které v důsledku intenzivního vývoje rychle zastarávají. Jakákoli produktová regulace by jistě neměla bránit účelným inovacím, na druhé straně inovační rychlost by neměla být zneuživána jako výmluva pro podporování návyků spotřebitelů ve smyslu neustálé výměny elektronických zařízení za modernější. ${ }^{26}$

Některé požadavky ekodesignu spolu navíc mohou soupeřit nebo se mohou vzájemně př́mo vylučovat. Tak například snadno může nastat situace, kdy odolnější výrobky budou mít sice prodlouženou životnost, ale o to hůře budou recyklovatelné, vytvořené z méně ekologických materiálů apod ${ }^{27}$ Problematika těchto ,dilemat ekodesignu“ ukazuje jak velmi je otázka jakékoli regulace navrhování produktů složitá a jak komplexně k ní musí být přistupováno, aby opatření, které se z hlediska jednoho aspektu jeví jako výhodné, nepřineslo problémy v aspektu jiném. ${ }^{28}$ Komplexnost těchto otázek by jistě neměla být překážkou jakékoli regulace, nicméně k celému procesu musí být přsistupováno velmi odborně, s vysokou mírou znalosti. Tento požadavek uvádí v obecné rovině i Zpráva o delší životnosti výrobků. ${ }^{29}$

\section{ZPU゚SOBY REGULACE}

V oblasti energetické účinnosti výrobků se osvědčilo ${ }^{30}$ stanovení určitých minimálních standardů, bez jejichž splnění nemůže být výrobek uveden na trh. I pro další oblasti regulace produktů se tak jako základní metoda nabízí vytvoření minimálních standardů. ${ }^{31} \mathrm{~V}$ tomto př́padě je možné postupovat v zásadě dvěma způsoby. Klasicky je možné vytvořit kritéria pro jednotlivé výrobky či skupiny výrobků, tedy regulovat i jiné aspekty obdobným způsobem jako energetickou účinnost podle směrnice o ekodesignu. Druhou možností je v budoucnu vytvořit standardy pro některé látky, prvky, materiály... V této souvislosti se již v tuto chvíli nabízí především regulace ve smyslu obligatorní recyklace kovů užitých v elektronických zařízeních. ${ }^{32} \mathrm{~V}$ souvislosti s tímto se také hovoří o minimálních standardech odolnosti, a to zejména s cílem zamezení využívání tzv. kazítek, tedy záměrnému zkracování životního cyklu výrobku s cílem jeho předčasné výměny za jiný (tzv. plánovanému zastarávání výrobků či softwaru). ${ }^{33}$

Jako další ryze právní nástroj je již částečně uplatňovaná rozširrená odpovědnost výrobce. ${ }^{34}$ Postavení tohoto právního nástroje by mělo být do budoucna v rámci Evropské unie posilováno a schémata rozšířené odpovědnosti by měla být zdokonalová-

26 Zejména problematika chytrých telefonů. Více $\mathrm{k}$ tomu mimo jiné Zpráva o uplatňování směrnice o ekodesignu, op. cit., s. 5.

27 Srov. PRENDEVILLE, $\mathrm{S}$. M et al. Uncovering ecodesign dilemmas: A path to business model innovation. Journal of Cleaner Production, 2017, vol. 143, s. 1337-1339.

28 Tento požadavek uvádí v obecné rovině i Zpráva o delší životnosti výrobků.

29 Zpráva o delší životnosti výrobků, op. cit., s. 7.

30 Pracovní program „Ekodesign“ 2016-2019, op. cit., s. 2.

31 Zpráva o provádění směrnice o ekodesignu, op. cit., s. 12.

32 Akční plán pro oběhové hospodářství, op. cit., s. 4.

33 Zpráva o delší životnosti výrobků, op. cit., bod 30.

34 Více: Institute for European Environmental Policy: EPR in the EU Plastic Strategy and the Circular Economy: A focus on a Plastic Packaging, 2017. Dostupná na: https://ieep.eu/uploads/articles/attachments /9665f5ea-4f6d-43d4-8193-454e1 ce8ddfe/EPR\%20and\%20plastics\%20report\%20IEEP\%2019\%20 Dec\%202017\%20final\%20rev.pdf?v=63680919827 [3. 6. 2019]. 
na. ${ }^{35} \mathrm{~V}$ souvislosti s odpovědností, některé dokumenty zmiňují za určitých podmínek prodloužení záruční doby o dobu nutnou k opravě. ${ }^{36}$ Otázkou pak také je, zda by v návaznosti na změny $\mathrm{v}$ př́stupu $\mathrm{k}$ hodnocení ekologičnosti výrobků neměla být kritéria trvalosti, opravitelnosti apod. začleněna mezi požadavky na udělení ekoznačky EU. ${ }^{37}$

Vedle uplatňování administrativně-právních nástrojů je často zmiňováno poskytování různých finančních podpor. ${ }^{38}$ Akční plán EU pro oběhové hospodářství $\mathrm{k}$ tomuto mimo jiné uvádí, že tržní signály nejsou v současnosti dostatečné $\mathrm{k}$ dosažení cíle ušetření zdrojů, nebot' veškeré subjekty participující na životním cyklu výrobků sledují tržní zájmy. ${ }^{39} \mathrm{Z}$ tohoto důvodu zmiňuje jako zásadní poskytování pobídek pro zlepšení designu výrobků, vytváření ekologicky uvědomělejších návrhů. V současnosti se objevují hlasy pro určitou formu podpor tzv. modulárních produktů, tedy těch, které svou konstrukcí odpovídají kritériu rozložitelnosti a zaměnitelnosti částí. O finančních podporách se dále hovoří zejména $v$ souvislosti se zvýšenou podporou opravárenského odvětví. ${ }^{40}$ Podpora oprav je považována za jeden z hlavních nástrojů v prodlužování životnosti výrobku a v minimalizaci vzniku odpadů, přičemž je očekávána velká vůle k opravě výrobků ze strany občanů Evropské unie. Průzkumy spotřebitelských preferencí totiž ukazují, že velké množství evropských občanů by dalo přednost opravě před koupí nového zboží, pokud by se neobávalo vysoké ceny opravy. ${ }^{41}$

\title{
6. ZÁVĚR
}

Závěrem lze tedy shrnout, že v současnosti dochází k přehodnocení vnímání pojmu ekodesign $\mathrm{v}$ evropském právu. Do budoucna se jím pravděpodobně bude rozumět celkový př́stup k navrhování výrobků, zahrnující jejich nejrůznější vlastnosti, nikoli jen energetickou účinnost. To je jistě krok správným směrem. Vytvořit účinnou a vhodnou regulaci kritérií, jako je životnost, odolnost, modernizace, znovupoužitelnost či recyklovatelnost produktu, však z mnoha důvodů nebude snadné. Vzhledem ke komplexnosti řešení těchto otázek lze do budoucna očekávat $\mathrm{v}$ této oblasti pouze drobné a dílčí úspěchy.

\author{
Mgr. BcA. Tereza Fabšíková \\ Právnická fakulta Univerzity Karlovy \\ fabsikot@prf.cuni.cz
}

35 Zpráva o delší životnosti výrobků, op. cit., s. 12.

6 Zpráva o delší životnosti výrobků, op. cit., s. 8.

7 Zpráva o delší životnosti výrobků, op. cit., s. 11.

38 Zpráva o provádění akčního plánu pro oběhové hospodářství ze dne 4. 3. 2019, op. cit., s. 3.

39 Zpráva o delší životnosti výrobků, op. cit., s. 21.

Zpráva o delší životnosti výrobků, op. cit., s. 8.

41 Více též Zpráva o delší životnosti výrobků, op. cit., s. 14 